\title{
Editorial
}

\section{The Four Pillars, the Financial Crisis and Demographics - Challenges and Opportunities}

\author{
Orio Giarini \\ The Geneva Association, via di Campo Marzio 4, Trieste, Italy. \\ E-mail: orio.giarini@alice.it
}

The Geneva Papers (2009) 34, 507-511. doi:10.1057/gpp.2009.26

IMF economists are suggesting that the public debt of the 10 richest countries will rise from 78 per cent of GDP in 2007 to 114 per cent by 2014 . $^{1}$ This means that these governments will then owe around U.S.\$50,000 for every one of their citizens. We know, moreover, that this borrowing will coincide with an increase in financial pressure brought about by the rising pension and healthcare costs of a greying population. By 2050, a third of the rich world's population will be over 60 years. The Economist article implies that "the demographic bill is likely to be ten times bigger than the fiscal cost of the financial crisis" and that one priority must be to rise retirement ages, so as to boost tax revenues (as people work longer) while cutting future pension costs. Many countries have already adopted such measures, but we believe that they need to go further and faster. Another key target is healthcare expenses.

A recent United Nations study indicates that, in the year 2050, the world population will include almost two billion people over 60 years, accounting for about 22 per cent of the total population. The majority of these "old" people will be living in the countries we define today as developing.

We believe that it is crucial not only to tackle these specific issues innovatively but also, in general, to adopt a much broader, longer-term and more far-sighted approach to the global demographic revolution. In this connection, there are a number of key considerations we should like to bring to our readers' attention.

First, the lengthening of the life cycle is a unique revolutionary phenomenon. It is having, and will continue to have, a profound impact on contemporary and future societies, and its effect on political and economic institutions is far deeper and more radical than is commonly realised. Of course, older people, over 70 and 80 years, have always existed. But whereas in the past, they tended to be very much the exception and constituted a tiny minority: today, with the lengthening of life, old age will be something the vast majority of people will experience. It has become, in short, a mass phenomenon. An analogy can be found in the economic history of the industrialised countries - since the beginning of the twentieth century, the illiterate poor have dwindled to a minority having for centuries previously been the majority. Moreover, the lengthening of the life cycle is a worldwide phenomenon. From the "older" industrialised countries, it is extending to almost all communities, everywhere. In all

\footnotetext{
${ }^{1}$ The Economist, June 13th 2009, page 11.
} 
countries, developing and industrialised alike, the contribution of the "over 60" population worldwide will be decisive.

However, the lengthening of the life cycle is often presented wrongly as the problem of an "ageing of the population", and, as such, as an indication of the decay of the industrialised world. In fact, the "older" countries have the enormous double advantage of being able to offer a longer (and better) life to their citizens and of being able to rethink the necessary subtle social, economic and political adaptations ahead of other countries. The problems they have already experienced will soon be affecting an increasing proportion of the rest of the world.

Second, in The Geneva Association, we have often said that what was really ageing was the notion of older age itself. Given the ability of each individual to be autonomous (in physical and/or mental terms), many studies and surveys indicate that, on average, a 70-year-old or even an 80-year-old, person, today corresponds to a person 15 or 20 years younger one century ago. Statistics based not on age but on the capacity to perform indicate in fact that, in many countries, the population is not "ageing" but "rejuvenating". In fact, we now live in a "counter-ageing society".

Third, the lengthening of the life cycle is clearly the result of economic and social advances closely linked to scientific and technological progress - in biology, medicine, health control, nano technologies, nuclear applications, communication, instrumentation and so on. This lengthening of the life cycle, in all its aspects, is therefore clearly the fundamental issue to keep in mind when discussing social policies. The financial crisis is a significant part of this overall picture, but clearly only one part. Fundamentally, the lengthening of the life cycle necessitates a redefinition of the ACTIVE period of life; many World Health Organization (WHO) studies and statistics have, among those of other agencies, been devoted to this issue. Active life should be considered under two distinct headings - on the one hand, remunerated work and, on the other, unpaid or voluntary activities. In fact, the two are complementary, and increasingly so in the post-industrial service economy.

Fourth, the lengthening of the life cycle implies an open opportunity (and in many instances the need) for extending retirement ages. At the time of the first provisions for retirement, a century ago, these were fixed at the average age of death, very close to the end of work life. Today, in many countries, at the official age of retirement, life expectancy tends to be as much as $15-20$ years.

Behind this thinking lies the crucial need to enhance human capital at all ages. We know that qualified workers enjoying job satisfaction retire around 2 years later than less qualified ones. But, of course, working conditions need to be adapted; a key factor is the promotion of part-time employment as an essential part of any well-balanced social security system and of employment for those over 60 years of age. In some northern European countries, partial pensions have been coupled with part-time work. Important also are gradual retirement plans and the possibility of a "four pillars system", based on the terminology of the Swiss three pillar system to which we, in The Geneva Association, have added a fourth pillar of retirement income, based on partial employment.

Fifth, health improvements necessarily involve a great increase in costs, not so long ago one could die almost "for free". Today, however, people must pay for the possibility of controlling, eliminating or reducing the effects of all sorts of illnesses and accidents. We are ready to spend large sums of money for the purchase and use of the 
mobility-conferring automobile, but in future, if we are to live and move longer, we will have to spend more and more on health maintenance.

From an economic point of view, retirement and health costs imply building individual financial savings as well as collective reserves efficiently distributed through dedicated fiscalities. We have here to do with nothing less than a new definition of the notion of capital (of its creation and use) in the post-industrial service economy and a new definition of "added value". Why, for example, is building and selling more cars accounted as an increase in GNP, while health costs, which increase our physical and mental well-being are not?

Sixth, a crucially important issue in which to invest research capacity in the coming decades is the reconsideration of measurements of the "Wealth of Nations", from which to derive the most appropriate benchmarks for improved welfare policies. In the service economy, not all measurements of "added value" indicate an increase in the level of wealth (for instance, do not internalise the cost of pollution management), while many developments in service functions and performance (for instance, in communication systems) add much more to real wealth than the usual added value references indicate. In particular, the notion of productivity in a service economy is much more relevant with reference to performance over time (hence in a probabilistic system) than to production factor costs (in an equilibrium based system). And, moreover, better health indicates that we are "richer". Such types of analysis are linked to progress in economics as a discipline, and to its engagement with environmental issues (which also attempts to solve the problems of the "Wealth of Nations", on the basis of their "sustainability").

By word of conclusion, working longer or later in life is still an issue handled with apprehension by politicians and society in general. However, in many cases, and with increasing frequency, working longer is a privilege. It depends, indeed, on the precondition of good health; it requires an adequate life-long education system and/or a life filled with positive learning experiences. It has to do with culture, interest in life, willingness to involve oneself as much as possible in a dynamic social environment. It is a fact that the "old poor" still exist, but a better society is a "counter-ageing" society where there is space and scope for active and, in a wider sense, productive ageing. The issue cannot simply be reduced to finding money to pay for idle people during the last 20 years of life. In any case, even if it were financially possible, it would impose an intolerable burden on younger generations.

\section{The pioneering role of The Geneva Association}

As early as the mid-1980s, The Geneva Association, conscious of changing demographic and financial trends, became concerned to assist with the crucial issue of the future financing of pensions and with rethinking some of the terms of social security. The dependency ratio of non-active retirees to the active population was already starting to erode rapidly, going from one to five in 1990 to one to three in 2020. For The Geneva Association, however, demographic trends - especially increased life expectancy - could also be seen as a positive opportunity, only if we were able to devise ways of enabling our "ageing" populations - most of whom enjoy 
better physical and mental health - to make a valid economic and social contribution to the functioning of our service economies over the decades to come.

Thus, the concept of a strategy based on "The Four Pillars" was born. The term fourth pillar owes its origin to the fact that in most countries the funding of pensions is based on resources drawn from three pillars:

- The first pillar is the compulsory state pension, based on the Pay-As-You-Go principle.

- The second pillar is the supplementary occupational pension normally based on various funding (capitalised) systems, though there are exceptions to this. It is interesting to note that several countries have recently made this complementary system compulsory.

- The third pillar is made up of individual savings (personal pensions, personal assets and life insurance).

- The fourth pillar involves supplementing the first three pillars with resources from a remunerated "productive" activity.

Two key measures appear to be crucial for the development of a fourth pillar - the promotion of part-time jobs (in many ways, and in any case, the only viable basis for a modern full employment policy) and the possibility of combining or cumulating wages with pensions in a number of different ways. In addition, the future of welfare is also linked to the formidable challenge posed by "Health and Ageing", an issue which The Geneva Association, with its special newsletter and annual conferences, has also studied in depth.

For over two decades now, research by The Geneva Association on the Four Pillars has been one of its most innovative activities, gaining increasing importance, particularly in the light of the situation described by The Economist at the beginning of this editorial. Among the major initiatives undertaken in this field, we should mention the following:

- We have prepared and edited more than 10 issues of The Geneva Papers on Risk and Insurance devoted to the Four Pillars strategy. The first one entirely dedicated to this issue was published in October 1996, introduced by a special lecture by Denis Kessler, former Vice-Secretary General of The Geneva Association, on the problem of "Preventing Conflicts between Generations". Already in January 1981, Denis Kessler had focused on the problem of "Social Security and Savings", together with Dominique Strauss-Kahn (now Director General of the IMF in Washington, DC). The book written by these two academics in 1982 L'épargne et la retraite-l'avenir des retraites préfinancées provided a key reference and starting point for our reflection.

- Almost from the very onset, the "Four Pillars" research has been monitored, managed and promoted by Geneviève Reday-Mulvey, who will retire in 2010 with great honours, having successfully devoted herself to what can only be described, socially and intellectually, as a "juste cause". She has organised dozens of conferences and participated in many more on this issue worldwide. She has painstakingly built up a network of researchers, a network, which is marked by a typically "Geneva Association" connotation, motivation. She has written and 
contributed to various publications and books, easy to find in The Geneva Association library and on its website.

- Patrick Liedtke, Secretary General and Managing Director of the Association since January 2001, has also contributed in various ways to this research. In particular, he has promoted, among others, the Silver Workers Institute and has been co-author of a book on The Employment Dilemma and the Future of Work of which the German version became an economic best seller.

- Since 2005, The Geneva Association programme on the Four Pillars has also been the inspiration behind the publication of the "European Papers on the New Welfare" (www.newwelfare.org).

This issue of The Geneva Papers on Risk and Insurance, we can safely state, is an evidence of sound and fruitful research, combining a response to short-term problems with long-term vision, on an issue to which each of us, whatever our activities or age, is fully committed. This is a unique initiative indeed, which has derived constant stimulation from its realistic approach to the challenge of envisaging and managing the future. It has been a signal privilege for The Geneva Association to bring its sense of business and social responsibility to bear on these issues and to have been able to elaborate and confirm intuitions born almost a quarter of a century ago. 